\title{
Pengembangan Laboratorium Virtual sebagai Media Pembelajaran: Peluang dan Tantangan
}

\author{
${ }^{1}$ Kurnia Muhajarah, ${ }^{2}$ Moh. Sulthon \\ ${ }^{1,2}$ Fakultas Dakwah dan Komunikasi, UIN Walisongo Semarang, Indonesia, \\ kurniamuhajarah@walisongo.ac.id, msulthon@walisongo.ac.id
}

\begin{abstract}
ARTICLE INFO
Article History:

Received : 08-09-2020

Revised : 17-11-2020

Accepted : 20-11-2020

Online : 30-11-2020

Keywords:

Laboratorium;

Laboratorium Virtual;

Media Pembelajaran

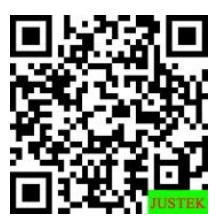

ABSTRACT

Abstract: Laboratory is a learning resource and learning media. The purpose of this research is what is the urgency of the laboratory as a learning medium and what are the opportunities and challenges of the virtual laboratory as a pedagogical framework overview. Therefore, researchers are interested in conducting studies on this matter. This research uses library research and is qualitative in nature. The result of this research is a laboratory as a place for activities that are needed in practice, which is often used as a standard for student success. Virtual laboratories have a significant impact in terms of preparing students for real-world experiences, as well as savings in equipment procurement and maintenance costs, flexibility in location, study time and practical use

Abstrak: Laboratorium merupakan salah satu sumber belajar dan media pembelajaran. Tujuan dari penelitian ini adalah bagaimanakah urgensi laboratorium sebagai media pembelajaran dan bagaimanakah peluang dan tantangan laboratorium virtual sebagai sebuah pedagogical framework overview. Oleh karena itu peneliti tertarik untuk melakukan kajian mengenai hal ini. Penelitian ini menggunakan jenis penelitian kepustakaan dan bersifat kualitatif. Hasil penelitian ini adalah laboratorium sebagai tempat kegiatan yang dibutuhkan dalam praktek, seringkali dijadikan standar kesuksesan mahasiswa. Laboratorium virtual mempunyai dampak signifikan dalam hal mempersiapkan mahasiswa untuk menghadapi pengalaman nyata, juga penghematan biaya pengadaan dan perawatan alat, fleksibilitas lokasi, waktu belajar dan praktek.
\end{abstract}

\section{A. LATAR BELAKANG}

Ada empat macam perubahan di dunia pendididikan telah menimbulkan banyak perhatian, yaitu ketika orang tua mulai sibuk dengan peran keluar sehingga tugas pendidikan anak sebagian digeser dari orang tua pindah ke guru atau dari rumah ke sekolah; terjadinya adopsi kata yang ditulis ke instruksi lisan; adanya penemuan alat untuk keperluan percetakan yang mengakibatkan ketersediaan buku lebih luas; dan adanya alat elektronika yang bermacammacam, mengakibatkan adanya akselerasi di dunia pendidikan (Andri, 2017)

Akselerasi di dunia pendidikan ditanggapi pula dengan pergeseran fungsi laboratorium. Laboratorium diharapkan mampu mengembangkan model-model pembelajaran inovatif yang selaras dengan perkembangan zaman. Perubahan sosio-kultural yang terjadi dengan akselerasi yang luar biasa cepat perlu disikapi dengan mengembangkan alternatif-alternatif kreatif dalam menyampaikan pembelajaran. Pengembangan ini sangat penting dalam rangka memberi bekal life skills pada mahasiswa agar dapat menghadapi tantangan perubahan sosial dan memberi manfaat bagi masyarakat luas. Perubahan di dunia pendidikan menuntut adanya inovasi 
pendidikan dengan teknologi merupakan satu kesatuan yang tidak dapat dipisahkan. Sadiman (1993) sebagaimana diadaptasi oleh Andri (2017), inovasi merupakan obyek dan teknologi pendidikan merupakan subyeknya. Keberadaan teknologi harus dimaknai sebagai upaya untuk meningkatkan efektivitas dan efisiensi dan teknologi tidak dapat dipisahkan dari masalah, sebab teknologi lahir dan dikembangkan untuk memecahkan permasalahan yang dihadapi oleh manusia. Keberadaan laboratorium vitual, menjadi salah satu bentuk akselerasi pendidikan.

Tujuan dari penelitian ini adalah bagaimanakah urgensi laboratorium sebagai media pembelajaran dan bagaimanakah peluang dan tantangan laboratorium virtual sebagai sebuah pedagogical framework overview. Oleh karena itu peneliti tertarik untuk melakukan kajian mengenai hal ini.

\section{B. METODE PENELITIAN}

Artikel ini menggunakan jenis penelitian kepustakaan (library research) dan bersifat kualitatif dikarenakan penelitian ini menjabarkan data deskriptif dan menelaahnya secara natural (Bogdan and Taylor: 1975). Creswell (2007) mengungkapkan sebagai penelitian yang mengumpulkan informasi yang ciri-cirinya berwujud kata-kata dan bukan rangkaian angkaangka. Penelitian kualitatif adalah penelitian yang berisi narasi terhadap peristiwa sosial yang ada.

\section{HASIL DAN PEMBAHASAN}

\section{Urgensi Laboratorium sebagai Media Pembelajaran}

Menurut Kamus Besar Bahasa Indonesia (1992: 1298), laboratorium adalah sebuah ruangan atau gedung yang digunakan untuk penelitian ilmiah, eksperimen dan tes. Laboratorium tidak hanya termasuk di dalamnya gedung atau ruang dan peralatannya saja. Akan tetapi pengertian laboratorium berkembang seiring dengan kebutuhan makna tempat pembelajaran bagi konsentrasi keilmuan tertentu. Selain laboratorium seringkali dimaknai sebagai tempat yang di dalamnya alat-alat pembelajaran, laboratorium juga dapat berbentuk seperti kampus atau kelas, alam atau lingkungan, lembaga sosial kemasyarakatan, dan bahkan masyarakat itu sendiri (Riyadi, 2019).

Adapun indikator laboratorium, menurut Damayanti (2008: 2) adalah: pertama, laboratorium dapat merupakan wadah yaitu tempat, gedung, ruang dan segala macam alat/perlengkapan yang diperlukan untuk kegiatan ilmiah. Dalam hal ini laboratorium dilihat sebagai perangkat keras (hardware). Dengan makna ini, maka laboratorium merupakan gedung tersendiri selain kelas. Kedua, laboratorium merupakan sarana media di mana dilakukan kegiatan belajar-mengajar. Dalam pengertian ini laboratorium dilihat sebagai perangkat lunak (software) dalam kegiatan ilmiah dan keberadaannya merupakan pelengkap pembelajaran. Ketiga, laboratorium dapat diartikan sebagai pusat kegiatan ilmiah untuk menemukan kebenaran ilmiah dan penerapannya. Sebagai tempat untuk menemukan kebenaran ilmiah, maka fungsi laboratorium dijadikan sebagai barometer dalam keberhasilan pembelajaran.

Luasnya makna laboratorium mengisyaratkan bahwa laboratorium dengan ragam bentuknya tidak akan habis untuk dijadikan sebagai sumber belajar dan media dalam proses belajar-mengajar. Laboratorium sebagai tempat kegiatan yang dibutuhkan dalam praktek seringkali dijadikan standar kesuksesan mahasiswa. Di sisi lain, fungsi laboratorium adalah sebagai berikut: pertama, sebagai tempat berlangsungnya kegiatan pembelajaran biologi secara praktek yang memerlukan peralatan khusus (Permendiknas No. 24 Tahun 2007); kedua, sebagai tempat yang dapat mendorong semangat mahasiswa untuk memperdalam pengertian dari suatu fakta yang diselidiki atau diamati (Emha, dkk, 2002: 7); ketiga, tempat display atau pameran (Koesmaji, dkk, 2004: 43); keempat, 
sebagai tempat bagi siswa untuk belajar memahami karakteristik alam dan lingkungan melalui optimalisasi keterampilan proses serta mengembangkan sikap ilmiah; kelima, sebagai tempat siswa berlatih menerapkan keterampilan proses sesuai dengan tuntutan pembelajaran Biologi yang mengutamakan proses selain produk (Nuryani, 2004: 147); keenam, memberikan kelengkapan bagi pelajaran teori yang diterima sehingga antara teori dan praktek bukan merupakan dua hal yang terpisah, melainkan dua hal yang merupakan suatu kesatuan. Keduanya saling mengkaji dan saling mencari dasar (Mustaji: 2009).

PP No. 33 Tahun 1985 ini senada dengan Pasal 43 Keputusan Menteri Agama No. 17 Tahun 1988, bahwa fungsi Laboratorium adalah untuk mempersiapkan sarana penunjang untuk melaksanakan pendidikan dan pembelajaran sesuai dengan bidang studi yang bersangkutan (Emha, dkk, 2002: 6). Melihat fungsi ini, maka fungsi laboratorium ditandaskan sebagai sebagai sarana penunjang dalam pembelajaran. Pembelajaran yang dimaksud tidak dibatasi pada ilmu praktek, seperti kimia, biologi (eksakta) semata, melainkan semua ilmu pengetahuan yang dipelajari di Perguruan Tinggi.

Terkait dengan ragam laboratorium pembelajaran, berdasar pada penggalian yang dilakukan peneliti, paling tidak ada 8 model laboratorium, yaitu: (a). Personalized System of Instruction (PSI). Laboratorium ini pertama kali dicetuskan oleh Keller (1968); (b). Audio Tutorial Method (A-T). Pendekatan ini dikembangkan oleh Portlethwart (1969-1972) yang merupakan metode dalam pembelajaran biologi di Purdue University; (c). Computer Assisted Learning (CAL). Computer Assisted Learning (CAL) sering dipakai di kalangan buruh oleh Inggris dan di kalangan guru-guru di Amerika Serikat; (d). Learning Aids Laboratory (LAL). Model ini merumuskan dimana mahasiswa terlibat dalam belajar secara individual dengan memakai sarana atau peralatan yang ada dalam laboratorium, misalnya AVA, komputer, pameran, percobaan sendiri atau studi referensi. Keberhasilan belajar dengan pendekatan LAL ini sangat tergantung pada motivasi mahasiswa itu sendiri, karena peralatan dalam laboratorium, baik yang hardware maupun software-nya tergantung pada niat, kemampuan, dan irama kerja dari mahasiswa sendiri; (e). Modular Laboratory (M-L), adalah model laboratorium di mana mahasiswa, dosen atau orang lain dapat melakukan kegiatan praktek (dalam arti belajar) dengan menggunakan modulmodul yang tersedia; (f). Integrated Laboratory (IL), adalah laboratorium yang terintegrasi berusaha mengintegrasikan atau memisahkan pada sub-sub disiplin ke dalam satu paket belajar dengan media laboratorium yang terintegrasikan; (g). Project Work, merupakan suatu pengalaman belajar tersendiri, di mana mahasiswa dihadapkan kepada masalah-masalah konkrit yang harus dipecahkan. Proyek di sini diartikan sebagai suatu unit praktek dari suatu kegiatan yang memiliki nilai pendidikan untuk menuju kepada satu atau lebih tujuan konkrit dalam hal penyelidikan dan pemecahan masalah yang sering dipakai dalam penggunaan materi fisik, direncanakan untuk disempurnakan oleh mahasiswa dan dosen dalam menuju suatu kehidupan nyata yang wajar; (h). Participation in Research (PIR). Dalam model ini, mahasiswa ikut serta dalam riset nyata yang sedang diadakan fakultas atau lembaga lain, misalnya Lembaga Penelitian, Lembaga Pengabdian pada masyarakat, dan sebagainya (Riyadi, 2019).

\section{Peluang dan tantangan Laboratorium Virtual: Pedagogical Framework Overview}

Laboratorium konvensional terdiri dari gedung dan ruangan yang menyediakan sarana prasarana teknologis penunjang pembelajaran yang disiapkan untuk praktek konten mata-mata kuliah berbobot praktikum. Pada dasarnya, kegiatan yang difasilitasi laboratorium konvensional adalah proses pembelajaran untuk penguatan kompetensi utama program-program studi, yang dilakukan, baik berbasis kelas di dalam maupun di 
luar gedung laboratorium. Prosedur operasional yang disimulasikan dikembangkan dari konten pratikum dari mata-mata kuliah berbobot praktikum sesuai dengan sarana dan prasarana teknologis yang ada di laboratorium konvensional (Sulton, 2020)

Dunia virtual adalah dunia yang diciptakan oleh ilusi digital untuk memberikan ruang rasa akan waktu dan tempat yang berisikan fenomena yang memiliki hubungan dengan "realitas." Fenomena atau "sesuatu" yang menjadi konten dunia virtual adalah tiruan dari realitas, representasi dari yang nyata dan ideal (Bunt: 2005, 15). Dengan demikian, laboratorium virtual dapat dibatasi sebagai sebuah realitas ruangan atau gedung di dunia maya yang dapat digunakan untuk penelitian ilmiah, ekperimen dan tes, yang memberikan ruang rasa akan waktu dan lokasi yang nyata dan sebenarnya.

Laboratorium virtual, menurut (Nirwana, 2017) adalah ruang praktek di dunia maya atau ruang sosial tempat para ilmuwan berinteraksi di dunia maya. Laboratorium virtual adalah suatu media yang digunakan untuk membantu memahami suatu pokok bahasan dan dapat memecahkan keterbatasan atau ketiadaan perangkat laboratorium (Chin, Myers, \& Hoyt, 2002). Menurut (Hermansyah, Gunawan, \& Herayanti, 2017) laboratorium virtual adalah suatu media berbasis komputer yang berisi simulasi kegiatan untuk menggambarkan reaksi-reaksi yang mungkin tidak dapat terlihat pada keadaan-keadaan nyata. Di lain sisi, laboratorium virtual (Liem, dkk, 2017) adalah suatu simulasi atau percobaan yang dilakukan di komputer untuk menyajikan fenomena alam yang memiliki peranan penting di dalam proses pembelajaran sains.

Berkaca dari beberapa pernyataan di atas, dapat disimpulkan bahwa laboratorium virtual adalah ruang simulasi untuk proses pembelajaran, atau ruang sosial di dunia maya, tempat para ilmuwan berinteraksi, mengatur ke dalam kelompok, mengembangkan hubungan, dan berbagi pendapat, ide, sumber daya, dan pekerjaan. Gambar 1 menyajikan mengenai posisi triangle antara pendidikan, humanities dan dunia digital atau virtual.

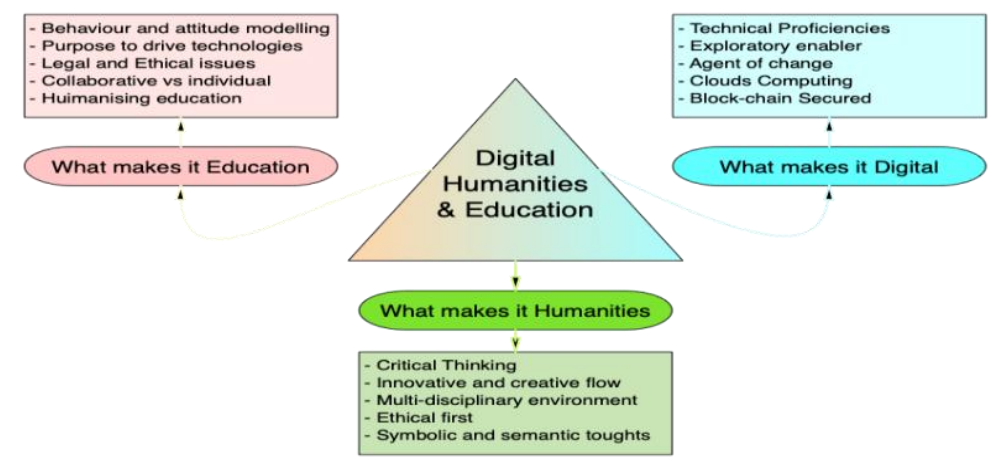

Gambar 1: Digital Humanities and Education

Sumber: Wahab. et al. 2010

Sejarah kelahiran laboratorium virtual tidak dapat dilepaskan dari proyek Essays and Resources on the Experimentalization of Life (1830-1930) yang diprakarsai oleh sebuah lembaga penelitian yang berlokasi di Berlin dengan nama Max Planck Institute for the History of Science. Dilansir dari Wikipedia, melalui proyek itu, lembaga penelitian yang berdiri tahun 1994 itu mencari dan menjelaskan berbagai hal yang berkaitan dengan interaksi antara teknologi, media, arsitektur dan ilmu kehidupan selama seratus tahun, antara 1830-1930. Hasil dari kajian berkelanjutan dibawah proyek tersebut kemudian dihimpun dalam bentuk digital dan menjadi konten laboratorium virtual (Thoha, 2020).

Kajian mengenai laboratorium virtual, bukanlah booming saat-saat pandemic saja. Ada beberapa kajian mengenai hal ini sebelumnya, yakni. Kajian terhadap laboratorium virtual yang berbasis web (Granado, Colmenares, Strefezza, \& Alonso, 2007) untuk obyek pembelajaran tanaman. Mereka menyimpulkan bahwa laboratorium virtual tidak dapat 
menggantikan pengalaman langsung di laboratorium konvensional, meskipun dengan laboratorium virtual, mahasiswa mempunyai pengalaman belajar yang seolah-olah mereka berada di dunia fisik untuk berinteraksi dengan obyek tanaman, dengan memeriksanya dari belakang atau di bawahnya, dan dari sudut pandang yang berbedabeda. Kedua, kajian terhadap laboratorium virtual untuk bidang pembelajaran instrumentasi dan pengukuran (Grimaldi \& Rapuano, 2009). Fokus kajiannya, pengalaman belajar secara virtual yang dialami mahasiswa dalam merancang laboratorium virtual. Ketiga, kajian terhadap laboratorium virtual untuk mata kuliah jaringan computer (Wolf, 2010). Kajiannya bertujuan menentukan dampak dari peristiwa pembelajaran dengan menerapkan Open Network Laboratory (ONL) yang dibandingkan terutama dengan perkuliahan.

Kajian terhadap laboratorium virtual di atas, menyatakan hal-hal sebagai berikut: Pertama, meskipun pengalaman pembelajaran dari lingkungan laboratorium virtual tidak dapat menggantikan pengalaman langsung dalam proses pembelajaran perkuliahan tatap muka langsung yang tetap masih diperlukan, namun hasil-hasil kajian di atas mengakui bahwa laboratorium virtual mempunyai manfaat dan berdampak signifikan antara lain dalam mempersiapkan mahasiswa untuk menghadapi pengalaman nyata. Di antara keunggulan dan nilai lebih lainnya adalah penghematan biaya pengadaan dan perawatan alat, fleksibilitas lokasi dan waktu belajar dan berpraktek, minimalisasi resiko destruktif jika terjadi kesalahan dan kekeliruan praktek serta lingkungan belajar yang interaktif.

Kedua, pembuktian atas manfaat laboratorium virtual untuk proses pembelajaran tersebut ditunjukkan dalam proses pembelajaran yang mengambil bidang-bidang kajian ilmu-ilmu kealaman dan sains. Ketiga, laboratorium virtual saat ini adalah remote laboratory. Laboratorium virtual menyediakan pengalaman pembelajaran yang memungkinkan mahasiswa atau peneliti melakukan eksperimen nyata dari jarak jauh melalui internet, dengan cara penggabungan data real dengan perangkat real, yang digerakan melalui remote laboratory (Wahab, 2020). Remote laboratory disebut juga mixed reality.
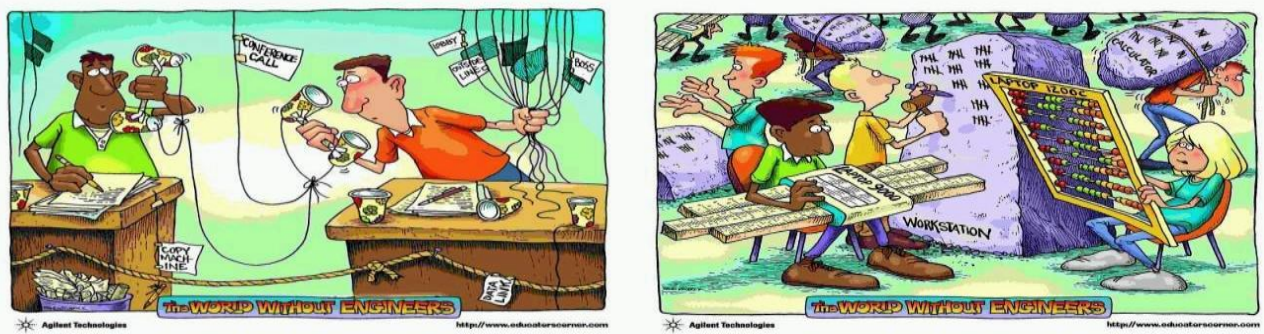

Gambar 2: Pentingnya Teknologi: The World without Engineers

Sumber: http://www.educatorscorner.com

Secara teknis, Jaya (2020) mengusulkan bahwa pengembangan komponen laboratorium virtual dapat dilakukan melalui: (a). Adanya materi: benda atau obyek yang berkaitan dengan kegiatan yang akan dipraktekkan, (b). Job Sheet, lembar kerja mahasiswa yang terdiri dari langkah-langkah kegiatan, pengisian table dan analisis data, (c). Simulasi, melalui komponen ini mahasiswa dapat melakukan simulasi dengan menirukan yang sudah dimodelkan, (d). Animasi 3 dimensi, komponen yang memvisualisasikan hal-hal abstrak, untuk mengatasi kesulitan memahami konsepkonsep abstrak dalam konteks dakwah, (e). Virtual representation (representasi dunia maya): obyek atau lingkungan dunia nyata yang direpresentasikan di dunia maya. Komponen ini memungkinkan mahasiswa untuk terlibat dalam pengalaman praktis dan tidak lagi berfikir abstrak di dunia maya, (f). Interactive tool. Komponen alat untuk proses 
interaksi dengan melakukan kegiatan, menggunakan konsep drag and drop (mengambil dan meletakkan) atau konsep play and pause (memainkan dan menghentikan sebentar).

\section{SIMPULAN DAN SARAN}

Adapun simpulan riset ini adalah sebagai berikut; (1) luasnya makna laboratorium mengisyaratkan bahwa laboratorium dengan ragam bentuknya tidak akan habis untuk dijadikan sebagai sumber belajar dan media dalam proses belajar-mengajar. Laboratorium sebagai tempat kegiatan yang dibutuhkan dalam praktek seringkali dijadikan standar kesuksesan mahasiswa; (2) keberadaaan pengalaman pembelajaran dari lingkungan laboratorium virtual tidak dapat menggantikan pengalaman langsung. Namun diakui, laboratorium virtual mempunyai manfaat dan berdampak signifikan dalam mempersiapkan mahasiswa untuk menghadapi pengalaman nyata. Di antara keunggulan dan nilai lebih lainnya adalah penghematan biaya pengadaan dan perawatan alat, fleksibilitas lokasi dan waktu belajar dan berpraktek, minimalisasi resiko destruktif jika terjadi kesalahan dan kekeliruan praktek serta lingkungan belajar yang interaktif.

Saran terhadap hasil riset ini, sebagaimana disampaikan oleh Murtadho (2020) yakni, menyarankan untuk menggunakan laboratorium virtual dengan menyiapkan SDM yang handal dalam teknologi virtual, sebagai terobosan pendidikan virtual yang dipercepat; perlunya penemuan atau perumusan model-model pembelajaran (Learning Management System, LMS) guna kecakapan penciptaan aplikasi-aplikasi; dan perlunya massifikasi produksi konten, a tau dalam istilah lain adalah pabrikasi konten, guna asupan virtual atas informasi bagi masyarakat.

\section{REFERENSI}

Andri, R. M. (2017). Peran dan Fungsi Teknologi Dalam Peningkatan Kualitas Pembelajaran. Jurnal Ilmiah Research Sains, 3(1), 122-129.

Bogdan, Robert and Steven J. Taylor. (1975). Introduction to Qualitative Research Methods, New York.

Chin, G., Myers, J., \& Hoyt, D. (2002). Social networks in the virtual science laboratory. Communications of the ACM, 45(8), 87-92. https://doi.org/10.1145/545151.545156

Creswell, John W. (2007). Qualitatif Inquiry and Research Design: Chosing Among Five Approaches, Second Edition, London: Sage Publications.

Damayanti, Anti, \& Isma Kurniatanty. (2008). Manajemen dan Teknik Laboratorium Prodi Biologi, Fakultas Saintek, UIN SUKA: Yogyakarta.

Emha, Saleh H., dkk. (2002). Pedoman Penggunaan Laboratorium Sekolah. Bandung: PT Remaja Rosdakarya.

Granado, E., Colmenares, W., Strefezza, M., \& Alonso, A. (2007). A web-based virtual laboratory for teaching automatic control. Computer Applications in Engineering Education, 15(2), 192-197. https://doi.org/10.1002/cae.20111.

Grimaldi, D., \& Rapuano, S. (2009). Hardware and software to design virtual laboratory for education in instrumentation and measurement. Measurement: Journal of the International Measurement Confederation, Vol. 42, pp. 485-493. https://doi.org/10.1016/j.measurement.2008.09.003

Hermansyah, H., Gunawan, G., \& Herayanti, L. (2017). Pengaruh Penggunaan Laboratorium Virtual Terhadap Penguasaan Konsep dan Kemampuan Berpikir Kreatif Siswa pada Materi Getaran dan Gelombang. Jurnal Pendidikan Fisika Dan Teknologi, 1(2), 97. https://doi.org/10.29303/jpft.v1i2.242

Jaya, Hendra, et.al. (2020). Praktek Simulasi Berbasis Websit, tn: Edukasi Mitra Grafika.

Koesmaji, W, dkk. (2004). Teknik Laboratorium. Bandung: Jurusan Pendidikan Biologi FMIPA UPI. 
Mustaji. (2015). Laboratorium: Perspektif Teknologi Pembelajaran. Workshop Penyusunan Panduan Penggunaan Laboratorium di Fakultas Ilmu Pendidikan Universitas Negeri Surabaya.

Nirwana, R. R. (2017). Pemanfaatan Laboratorium Virtual Dan E-Reference Dalam Proses Pembelajaran Dan Penelitian Ilmu Kimia. Phenomenon : Jurnal Pendidikan MIPA, 1(1), 115. https://doi.org/10.21580/phen.2011.1.1.447

Nuryani, R. (2004). Strategi Belajar Mengajar Biologi. Malang: Penerbit Universitas Negeri Malang. Lampeter. Gary R. Bunt. (2005). Islam Virtual: Menjelajah Islam di Jagad Maya, terj Suharsono. Yogyakarta: Suluh Press.

"Pemodelan Laboratorium Virtual Sains." DOI: 10.13140/RG.2.2.10990.61767. https://www.researchgate.net/publication/314434868_Pemodelan_Laboratorium_Vir tual_Sains

Murtadlo, M. (2020). Kebijakan dan Inovasi Pendidikan Berbasis Lab Virtual.

Riyadi, A. (2019). Desain Pengembangan Laboratorium Dakwah: Studi Kasus UIN Walisongo Semarang. Jurnal Komunikasi Islam, 09(2).

Riyana, Cepi. (2017). Peranan Teknologi dalam Pembelajaran. https://www.researchgate.net/publication/242646955

Sulton, M. (2020). Laboratorium Virtual: Reformulasi Fungsi Laboratorium dakwah bagi Peningkatan Mutu Akademik dan Riset n.

Thoha. (2020). PhET Aplication Program: Strategi Menguatkan Pemahaman Siswa pada Materi Listrik DC melalui Pembelajaran Berbantu Lab Virtual. Jurnal Pendidikan Madrasah, 4(2), 157-169. https://doi.org/10.14421/jpm.2019.42-04

Wahab, A. (2020). International Webinar Faculty Of Da'wa And Communication.

Wahab. et al. (2010). "EEG Signals for Emotion Recognition". Journal of Computational Methods in Sciences and Engineering.

Wolf, T. (2010). Assessing student learning in a virtual laboratory environment. IEEE Transactions on Education, 53(2), 216-222. https://doi.org/10.1109/TE.2008.2012114

Wibawanto, Wandah. (2020). Laboratorium Virtual: Konsep dan Pengembangan Simulasi Fisika. Penerbit: LPPM UNNES.

Wikipedia. (2018). "Virtual Laboratory," https://en.wikipedia.org/wiki/Virtual_Laboratory 